створення структур, форм і технологій, що їх забезпечують. В інформаційному суспільстві особлива роль у розв'язанні цього завдання належить дистанційній освіті.

Слід зауважити, що становлення інформаційного суспільства змінює парадигму мислення: теоретичне фундаментальне мислення, яке грунтується на зразках науки, перебуває у кризі, тому що втрачається єдиний культурний вектор, при цьому соціальні практики стають інтелектуально насиченими, підвищуються вимоги до свідомої цілеспрямованої діяльності. Отже, сучасна гуманітарна освіта стає фундаментальною підготовкою, яка визначається не трансляцією фундаментальних знань (універсальний та єдиний контекст дослідження втратив силу), а зорієнтованого на формування творчої здатності як фундаментальної структури людського буття, на концептуалізацію діяльності, що має продуктивні теоретичні потенції.

Міждисциплінарний підхід сприяє реалізації всіх дидактичних принципів навчання. Перспективами подальших досліджень $є$ опис практичної реалізації міждисциплінарного підходу на заняттях іноземної мови.

\title{
Література
}

1. Андреев А.Л. Гуманитарное образование : очередной кризис? / А. Л. Андреев // Высшее образование в России. - 2004. - № 7. - С. 95-103. 2. Завьялова М. П. Изменения установок гуманитарного образования в условиях становления информационного общества [Электронный ресурс] / М. П. Завьялова, Д. В. Сухушин // Открытый междисциплинарный электронный журнал «Гуманитарная информатика». - Вып. 1. - Томск : Томский гос. ун-т. Режим доступа: http://huminf.tsu.ru/e-jurnal/magazine/1/zavalov.htm 3. Санникова О. В. Междисциплинарность содержания социально-гуманитарного образования : социокультурные основания / О. В. Санникова // Высшее образование в России. - 2009.№ 4. - С. 98-103. 4. Микешина Л. Л. Трансцендентальное измерение гуманитарного знания / Л. Л. Микешина // Вопросы философии. $-\quad 2006 .-\quad № 1 .-\quad$ С. 46-67. 5. Хуторской А. В. Дидактическая эвристика. Теория и технология креативного обучения : [монография ] / Андрей Викторович Хуторской. - Москва : Изд-во МГУ, 2003. - 416 с.

$$
\begin{gathered}
\text { УДК (37.026:159.922.72)-043. } 86:([005.336 .2: 17.023 .36-\quad \text { Дар’я Фурт } \\
022.218]: 373.5 .046-021.66
\end{gathered}
$$

\section{ДИДАКТИЧНІ УМОВИ РОЗВИТКУ ПОЛІКУЛЬТУРНОЇ КОМПЕТЕНТНОСТІ СТАРШОКЛАСНИКІВ}

\author{
Фурт Д. В. Дидактичні умови розвитку полікультурної компетентності \\ старшокласників. \\ У статті проаналізовано погляди науковців на досліджувану проблему, визначено
} основні дидактичні умови розвитку полікультурної компетентності старшокласників на уроках англійської мови. 3'ясовано поняття «дидактичні умови»; розглянуто основні форми роботи зі старшокласниками та визначено необхідні чинники для ефективного розвитку полікультурної компетентності. У роботі наголошено, що за умов методично грамотно організованої роботи 3 розвитку полікультурної компетентності, учні опановують загальноприйняті норми мовного спілкування і мовної поведінки в культурному середовищі, мова якого вивчається, та у своєму рідному.

Ключові слова: умови, дидактичні умови, полікультурна компетентність, розвиток полікультурної компетентності, старшокласники, форма роботи, мовне середовище.

Фурт Д. В. Дидактические условия развития поликультурная компетентность старшеклассников.

В статье проанализированы взгляды ученых на исследуемую проблему, определены основные дидактические условия развития поликультурной компетентности старшеклассников на уроках английского языка. Выяснено понятие «дидактические 
условия»; рассмотрены основные формы работы со старшеклассниками и определены необходимые факторы для эффективного развития поликультурной компетентности. В работе отмечается, что в условиях методически грамотно организованной работы по развитию поликультурной компетентности, учащиеся овладевают общепринятыми нормами языкового общения и речевого поведения в культурной среде, язык которого изучается, и в своей родной.

Ключевые слова: условия, дидактические условия, поликультурное компетентность, развитие поликультурной компетентности, старшеклассники, форма работы, языковая среда.

Furt D. V. Diadic conditionals of senior high school students' policultural competence development.

Nowadays there are many problems in Ukrainian education environment, that's why it is necessary to create such conditions that some psychological merits can be created in the senior high school students' minds. In the article the main didactic conditions of senior high school students' policultural competence development at English lessons are described. The views of some scientists on this problem are considered. The notion «didactic conditions» is identified. The condition is a situation in which something is created or developed. The main forms of work with senior high school students for successful development of the policultural competence are considered. Necessary factors for effective work are identified.

It is very important to integrate policultural information with main school curricula of major subjects because it is almost impossible to develop policultural competence only at the English lessons.

It should be noted that the policultural competence effectiveness depends on the relationship of academic and extracurricular activities (clubs, exhibitions, contests, conferences, meetings etc.).

The next condition for policultural competence development is defined as one that helps to create a cultural space for successful policultural conscience development and self-realization in the family or youth organizations.

Cultural environmental organization at school is when students, considering their traditions and stereotypes, may act independently in gaining practical experience and reveal the world of different cultures. Senior high school students' evaluation other individuals without stereotypes, the critical and logical thinking development are the results of cultural environmental organization; it depends on the variability of foreign languages training programs.

So, didactic conditions can encourage policultural education of senior high school students' process; they help students to create their own life position and to accept other different cultures without critical attitude to them.

Didactic conditions are the circumstances of the learning process; they are the result of purposeful selection and usage of teaching methods that make the development of policultural competence successful.

Key words: conditions, didactic conditions, policultural competence, the development of policultural competence, senior high school students, forms of work, cultural environmental, training programs.

Зміни в суспільстві, які наразі відбуваються (політична та економічна нестабільність, загострення національних відносин, конфліктність у спілкуванні, прояв жорстокості тощо), викликали низку актуальних проблем у навчанні та вихованні. У таких соціальнопедагогічних умовах виникає потреба перегляду концепції, мети i завдань освіти та розроблення нового дидактичного інструментарію.

Л. Виготський указував на необхідність заздалегідь створювати умови, що слугуватимуть для розвитку відповідних особистісних якостей [2, с. 55].

Mema cmammi - проаналізувати різні погляди на дидактичні умови та окреслити власні задля успішного розвитку полікультурної компетентності старшокласників.

Визначаючи дидактичні умови формування полікультурної компетентності 
старшокласників, апелюємо до того, що «умова»- це обстановка, у якій відбувається щонебудь, основа, передумова для чого-небудь [7, с. 518-519]; необхідна обставина, що уможливлює здійснення чого-небудь або сприяє чомусь [8, с. 442].

У філософському словнику «умова» тлумачиться як те, від чого залежить щось інше (зумовлене), що уможливлює наявність речі, стану, процесу, на відміну від причини, що 3 необхідністю, неминучістю породжує що-небудь (дія, результат дії), і від підстави, що є логічною умовою наслідку [9, с. 469]. Отже, з філософської позиції, «умова»- це чинник, завдяки якому річ або процес виникає та функціонує.

В. Буряк, аналізуючи проблеми організації оптимального освітнього простору для здійснення ефективної навчально-пізнавальної діяльності, виокремлює такі дидактичні умови: організація навчання відповідно до ієрархічної закономірності процесу засвоєння знань (від нижчого рівня до вищого); цілеспрямована педагогічна діяльність щодо активізації у осіб, які навчаються, операційних структур мислення; формування у слухачів навичок самоорганізації; зміщення акцентів у навчанні з передачі знань на опанування способами дії 3 ними; адекватне застосування методик констатувального та корегувального контролю [1, c. 25-27].

Отже, під дидактичними умовами, які визначають успішність розвитку полікультурної компетентності старшокласників, розуміємо обставини процесу навчання, що $\epsilon$ результатом цілеспрямованого вибору, конструювання й застосування елементів змісту, методів навчання, завдяки яким процес розвитку полікультурної компетентності може бути успішним.

Розвиток полікультурної компетентності старшокласників на профільному рівні навчання іноземної мови може бути успішним завдяки упровадженню певних дидактичних умов.

Першою умовою $є$ інтегрування полікультурної інформації з основним програмовим матеріалом навчальних предметів. Вона має реалізовуватися під час навчальної діяльності та передбачає забезпечення зв'язку полікультурної інформації 3 основним програмним матеріалом навчальних предметів. Щоб забезпечити цей зв'язок, необхідно проаналізувати нормативні документи, теорію та практику освіти. Такий аналіз здійснила Т. Поштарьова, яка виокремила п'ять моделей уведення національно-регіонального компонента до змісту загальної освіти. Ці моделі є універсальними і можуть використовуватися задля уведення полікультурної інформації до змісту освіти, а саме: міжпредметна модель - передбачає розподіл відповідної інформації 3 усіх навчальних предметів; модульна модель реалізується за допомогою залучення до предмета іноземної мови циклу спеціальних тем (модулів), що відображають етнокультурну своєрідність регіону; монопредметна модель передбачає поглиблене вивчення школярами культури, мова якої вивчається, історії, географії країни на заняттях зі спеціально виокремлених для цієї мети навчальних предметів; комплексна модель реалізується у вигляді інтегративних курсів, у яких окремі аспекти іншомовної культури можуть бути подані у взаємозв'язку історії та краєзнавства тощо; доповнювальна модель передбачає ознайомлення 3 етнокультурною інформацією в ході позакласних і позашкільних заходів [6].

3 погляду І. Звєревої, є три види міжпредметних зв’язків, в основу яких покладено принцип системності [3].

На підставі того, що розвиток полікультурної компетентності старшокласників достатньо тривалий процес, необхідно використовувати не одну форму навчання. Для цього потрібно складати план перспективної роботи на рік, визначаючи зміст, форму, засоби ознайомлення учнів старших класів 3 іншомовною культурою. Цей план роботи має грунтуватися на загальнодидактичних принципах науковості, концентричності, доступності, зв'язку теорії з практикою, свідомості й активності учнів.

Ми дійшли висновку, що необхідними умовами міждисциплінарної інтеграції у розвитку полікультурної компетентності є: уникнення «вузькості» дисциплін, що призводить до фрагментарності полікультурних знань; разом 3 поглибленим висвітленням проблем 
певної науки доцільно демонструвати їі полікультурний компонент; зв'язок предметів, які вивчаються, з тими, у яких полікультурний компонент подано повніше (наприклад, із дисциплінами гуманітарного циклу); систематичне обговорення конкретних форм зв'язків між предметами, розділами, темами тощо.

Також одними 3 ефективних чинників для створення умов розвитку полікультурної компетентності старшокласників служать тренінги та семінари (командна робота, лідерство, комунікація, технології переконливого впливу тощо), а також організація клубів за інтересами, тематичних виставок-завдань.

Отже, навчальні дисципліни за умов методично грамотної організованої роботи 3 розвитку полікультурної компетентності не тільки можуть, а й повинні виявитися результативними, оскільки учні опановують загальноприйняті норми мовного спілкування $\mathrm{i}$ мовної поведінки в українськомовному культурному середовищі.

Важливою дидактичною умовою є реалізація принципу системності, який забезпечує взаємозв'язок навчальної та позанавчальної діяльності у процесі розвитку полікультурної компетентності.

Ефективність розвитку полікультурної компетентності залежить від взаємозв'язку навчальної та позанавчальної діяльності. Остання відбувається у процесі різноманітних заходів: позаурочних (предметні гуртки, секції, виставки, тощо); позакласних (збори, класні години, вечори спілкування, свята, виставки, екскурсії, походи, музейна діяльність тощо); позашкільних (конкурси, тематичні екскурсії, фестивалі, конференції, семінари тощо).

Позанавчальна діяльність учнів визначається як ефективна форма роботи, організована задля розвитку їхньої особистості. Позанавчальні заходи надають старшокласникам більшу самостійність, ініціативу, свободу творчості, сприяють згуртуванню учнівського колективу, надають їм змогу розкрити і реалізувати свої здібності.

Організація позанавчальних заходів полікультурної спрямованості має будуватися за принципами послідовності й наступності логічно взаємопов'язаних групових i масових позаурочних заходів, які розкривають певну тему, проблему або напрям, зокрема, $\epsilon$ спрямованими на розвиток полікультурної компетентності старшокласників.

Якщо в навчальній діяльності процес розвитку полікультурної компетентності за своєю сутністю є індивідуальним, то в позанавчальній роботі їі формування виражається у взаємодії індивіда з іншими, не схожими в етнокультурному плані особистостями, забезпечуючи іiі становлення. Усе різноманіття етноорієнтованих форм позаурочної роботи 3 учнями можна умовно поділити на чотири групи залежно від основного завдання: 1) соціально орієновані форми («круглі столи», конференції, класні години, зустрічі 3 представниками різних етнічних діаспор, істориками, етнографами, діячами культури, випуск газет тощо); 2) пізнавальні форми (краєзнавчі й етнографічні екскурсії, походи, дні культури й фестивалі, усні журнали, вікторини, тематичні вечори, музейна діяльність, студії, секції, гуртки, виставки тощо); 3) практико орієнтовані форми (тренінги, рольові ігри, шефська і благодійна діяльність тощо); 4) розважальні форми (вечори, народні свята, ярмарки, фольклорні концерти й театральні вистави, змагання з національних видів спорту та народних ігор тощо) [6, с. 198].

Значення позанавчальної діяльності для розвитку полікультурної компетентності важко переоцінити, оскільки саме в ній учні не просто відтворюють усе те, що засвоїли у процесі навчання. Завдяки унікальності та неповторності позанавчальної діяльності, а саме: невимушеному та неформальному спілкуванні, вільному вибору форм і засобів діяльності, використання їх на свій розсуд - учні розвивають та доповнюють свої полікультурні знання й навички, удосконалюючи полікультурну компетентність. Взаємозв'язок навчальної та позанавчальної діяльності виявляється в тому, що практична діяльність, яку учень здійснює в позанавчальний час, стимулює його пізнавальну активність і вимагає наявності певних теоретичних полікультурних знань, стимулюючи тим самим навчання у школі.

Отже, якщо навчальна діяльність учнів закладає основи для всебічного розвитку особистості, то позанавчальна діяльність створює умови для підвищення ефективності 
урочної діяльності. Тому позанавчальна діяльність $є$ органічним продовженням навчальної діяльності й передбачає використання різноманітних форм i методів, спрямованих на розвиток полікультурної компетентності учнів.

Крім цього, позанавчальна діяльність, що має полікультурну спрямованість, має яскраво виражену специфіку впливу на особистість [5, с. 342-346].

Позанавчальна діяльність надає великі можливості для розвитку полікультурної компетентності старшокласників, але, як це не прикро констатувати, у сучасних умовах вона впроваджується не систематично. При цьому, як свідчить практика, результативність роботи значно поліпшується, коли така робота здійснюється у співтворчості школи та національнокультурних товариств національних меншин.

Ми пропонуємо такі позанавчальні заходи: 1) вечори дружби за присутності іноземних гостей; 2) мовні олімпіади із залученням полікультурного матеріалу; 3) зустрічі 3 учасниками поїздок у полікультурні табори, а також студентами, які працювали в країнах Європи та США; 4) участь у різноманітних науково-практичних конференціях 3 доповідями на полікультурну тематику; 5) волонтерська діяльність: гуманітарна допомога та театралізовані виступи у дитячих будинках та інтернатах для дітей 3 обмеженими можливостями; 6) відвідування різноманітних виставок полікультурного характеру; 7) проведення конкурсів творів та доповідей, круглих столів, вікторин, перегляд фільмів та читання аутентичних текстів, організація свят та заходів англійською мовою.

Отже, з одного боку, залучення учнів і їхніх батьків до полікультурних заходів сприяє грунтовнішому пізнанню культури свого етносу, а 3 іншого, - популяризує кращі зразки національних культур інших народів, що, у свою чергу, сприятливо впливає на розвиток полікультурної компетентності старшокласників. Залученню батьків до участі в полікультурних заходах надається велика увага, оскільки практика доводить, що основу для розвитку полікультурної компетентності в дітей закладає саме родина. У зв'язку з цим зростає роль родини у формуванні міжетнічної толерантності, позитивного образу своєї етнічної культури та інших етнічних культур.

Третю дидактичну умову ми визначили як таку, що сприяє створенню культурного простору, який впливатиме на розвиток полікультурної свідомості, мислення, креативної самореалізації в сім'ї, школі, молодіжних організаціях.

Н. Крилова розглядає культурний простір як систему, складниками якої є культурне, освітне, навчальне, комунікаційне та інформаційне середовища [4].

Однак варто зазначити, що на характер і світогляд особистості, на ставлення до представників своєї та інших культур впливають етнічні особливості етнокультурного середовища. Цей феномен досліджувало багато науковців: В. Козлов, Н. Лебедєва, П. Степанов. Вони вбачають в основі такого середовища традиції та стереотипи народів, завдяки яким відбувається комунікація і взаєморозуміння людей. Відповідно, етнокультурне середовище учня залежить від регіону, умови якого формують ставлення до освітніх та культурних потреб.

Організація культурного простору у школі полягає в тому, щоб учні, розглядаючи свої традиції та стереотипи, могли виявити самостійність у набутті практичного досвіду і усвідомити світ різних культур за допомогою свого творчого саморозкриття. Оцінювання старшокласниками інших індивідів, не вдаючись до стереотипів, розвиток критичного i логічного мислення, застосування отриманих результатів до різноманітних проблем та питань відбувається завдяки організації культурного простору. Від варіативності й різноманітності тематичного наповнення навчальних програм з іноземної мови залежатиме рівень розвитку полікультурної компетентності.

Організація культурного простору реалізується в різних формах: на інтегрованих уроках, класних годинах і спецкурсах 3 країнознавства, загальношкільних олімпіадах, конференціях, конкурсах, під час дослідницької діяльності учнів, підготовки доповідей і тез, у сюжетно-рольових і ділових іграх, театралізації, у формах дозвільної діяльності і зустрічах 3 представниками інших культур. У сучасному світі культурний простір безпосередньо 
залежить від засобів масової інформації (телебачення, радіо, Інтернет тощо), які змінюють життя людини не тільки у вияві зовнішніх знакових форм, а й за допомогою зміни способу його життя. Завдяки сучасним комунікативним технологіям рівень міжособистісних, міжгрупових та міжкультурних контактів стрімко зростає.

Отже, дидактичні умови стимулюють процес полікультурної освіти старшокласників і сприяють формуванню в учнів особистісних позицій, відкритого багатогранного бачення світу і прийняття культури іншої особистості. Однак без спеціальної цілеспрямованої роботи неможливо досягти позитивних змін у полікультурній свідомості старшокласників.

\section{Література}

1. Буряк В. К. Система дидактичних умов ефективної організації навчальної пізнавальної діяльності / $\quad$ В.К.Буряк // Рідна школа. - 2007 - № 92. Выготский Л. С. Развитие высших психических функций / Л. С. Выготский. - Москва : Изд-во АПН РСФСР, 1960. - 598 с. З. Зверева И. Д. Межпредметные связи в современной школе / И. Д. Зверева, В. Н. Максимова. - Москва: Педагогика, 1981. - 160 с. 4. Крылова Н. Б. Культурология образования / Н. Б. Крылова. - Москва : Народное образование, 2000. - 272 с. 5. Перетяга Л. Є. Дидактичні умови формування полікультурної компетентності молодших школярів / Л. С. Перетяга // Педагогіка і психологія формування творчої особистості : проблеми і пошуки : збірник наукових праць. - Запоріжжя, 2009. - Вип. 54. - С. 342-346. 6. Поштарёва Т. Теория и практика формирования этнокультурной компетентности учащихся в полиэтнической образовательной среде: [монография]/ Т. Поштарёва. - Ставрополь : Литера, 2006. - 300 с. 7. Педагогический энциклопедический словарь / науч. ред. О. Д. Грекулова. - Москва: Большая рос. энцикл., 2003. - 528 с. 8. Словник-довідник з української лінгводидактики: [навч. посібник] / кол. авторів за ред. М. Пентилюк. - Київ : Ленвіт, 2003. - 149 с. 9. Современный философский словарь [Текст] / под ред. Г. М. Коджаспировой, А. Ю. Коджаспирова. - Екатеринбург : Одиссей, 1996. $450 \mathrm{c}$.

Ганна Шалацька

\section{НОВІТНІ ПІДХОДИ ДО ВИКЛАДАННЯ ДІЛОВОЇ ІНОЗЕМНОЇ МОВИ ЗА ПРОФЕСІЙНИМ СПРЯМУВАННЯМ: ІНФОРМАЦЙНІ ТЕХНОЛОГІЇ}

Шалацька Г. М. Новітні підходи до викладання ділової іноземної мови за професійним спрямуванням: інформаційні технології.

У статті розглянуто питання методики викладання ділової іноземної мови за професійним спрямуванням студентам спеціальності «Інформаційні технології». Наведено приклади типових вправ та завдань для відпрацювання лексичного матеріалу, ситуацій ділового спілкування. Окреслено основні етапи роботи над засвоєнням матеріалу, призначеного для вивчення ділової англійської мови за професійним спрямуванням. Вказано на шляхи розширення світогляду студентів та мотивації їх самостійної роботи з предмета. Визначено перспективи подальших досліджень з цієї проблеми.

Ключові слова: інформаційні технології, тенденція, галузь знань, Інтернет, професійна сфера, інтенсифікація, мотивація, освітня платформа.

Шалацкая А. Н. Новейшие подходы к преподаванию делового иностранного языка по профессиональной направленности: информационные технологии.

В статье рассмотрены вопросы методики преподавания делового иностранного языка по профессиональной направленности студентам специальности «Информационные технологии». Приведены примеры типовых упражнений и заданий с целью отработки лексического материала, ситуаций делового общения. Очерчено основные этапы работы над освоением материала, предназначенного для изучения делового английского языка по профессиональной направленности. Указаны пути расширения кругозора студентов и 